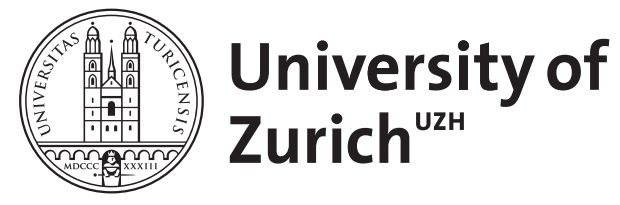

Zurich Open Repository and Archive

University of Zurich

University Library

Strickhofstrasse 39

CH-8057 Zurich

www.zora.uzh.ch

Year: 2005

\title{
Expanding the Spectrum of Helicobacter pylori-Associated Diseases
}

Zbinden, $\mathrm{R}$

DOI: https://doi.org/10.1007/s15010-005-7205-3

Posted at the Zurich Open Repository and Archive, University of Zurich

ZORA URL: https://doi.org/10.5167/uzh-156378

Journal Article

Published Version

Originally published at:

Zbinden, R (2005). Expanding the Spectrum of Helicobacter pylori-Associated Diseases. Infection, $33(2): 49$.

DOI: https://doi.org/10.1007/s15010-005-7205-3 


\title{
Expanding the Spectrum of Helicobacter pylori-Associated Diseases
}

\author{
R. Zbinden
}

Helicobacter pylori is generally accepted as a cause of upper gastrointestinal pathology, but its association with other clinical entities, e.g. coronary artery disease, is very difficult to prove. A new association of $H$. pylori and idiopathic central serous chorioretinopathy has recently been suggested [1]. In this issue of INFECTION Otasevic et al. describe patients with anterior uveitis who have antibodies against $H$. pylori in the aqueous humor [2]. The detection of specific antibodies in aqueous humor is a very interesting approach to associate an ocular clinical entity with an infectious agent. However, this does not prove an infection with the corresponding agent because antibodies produced during a systemic infection can diffuse from the blood into the eye. Therefore, the demonstration of intraocular specific antibodies should be correlated with other serum proteins to prove that those antibodies are produced locally. This is similar to the detection of intrathecal antibodies of infections of the central nervous system, e.g. neuroborreliosis. The published paper could not prove the intraocular production of the specific antibodies, but we decided to publish this paper to motivate other groups to look for specific locally produced antibodies to sustain or to deny this new association of $H$. pylori and anterior uveitis.

Another study published in this issue deals with the difficulty to cultivate $H$. pylori, if the gastric biopsy has to be sent by overnight courier to a microbiological laboratory [3]. A commercial transport medium was suitable for the overnight transport of gastric biopsy specimens to a specialized microbiological laboratory without loss of the viability of $H$. pylori. This paper demonstrates that the overnight transport of gastric biopsies to cultivate $H$. $p y$ lori for determination of antibiotic resistance is also pos- sible for hospitals or gastroenterologists in private practice, as resistance testing may be useful in case of eradication failure. Furthermore, the study reports the frequency of resistance to clarithromycin and metronidazole both for a Swiss district hospital and for the last 10 years in a university hospital.

\section{References}

1. Giusti C, Mauget-Faysse M: Helicobacter pylori and idiopathic central serous chorioretinopathy. Swiss Med Wkly 2004; 134: 395-398.

2. Otasevic L, Walduck A, Meyer TF, Aebischer T, Hartmann C, Orlic N, Pleyer U: Helicobacter pylori infection in anterior uveitis. Infection 2005; 33: 82-85.

3. Yuen B, Zbinden R, Fried M, Bauerfeind P, Bernardi M: Cultural recovery and determination of antimicrobial susceptibility in Helicobacter pylori by using commercial transport and isolation media. Infection 2005; 33: 77-81.

Infection 2005; 33: 49

DOI 10.1007/s15010-005-7205-3 